
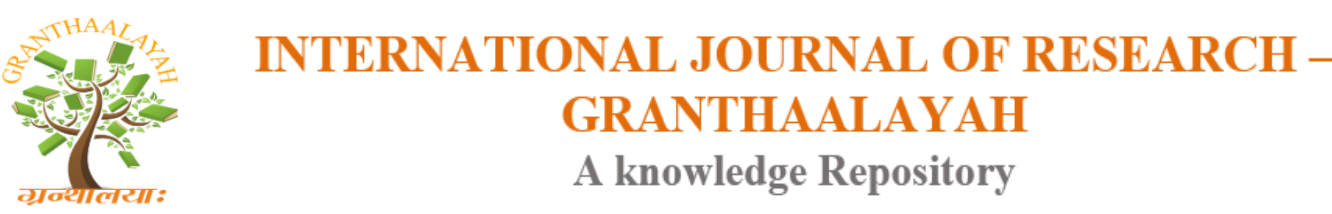

Science

\title{
DESIGN AND ANALYSIS OF DUAL BAND H SHAPED RECTANGULAR MICROSTRIP PATCH ANTENNA
}

\author{
Saima Tabassum Mansoori ${ }^{1}$, Prof. Rahul Koshta ${ }^{2}$ \\ ${ }^{1}$ M.Tech (Student), Microwave Engineering, Department of Electronics \& Communication \\ Engineering, S.R.I.T. Jabalpur (M.P.), India \\ ${ }^{2}$ Professor, Department of Electronics \& Communication Engineering, S.R.I.T. Jabalpur (M.P.), India
}

\begin{abstract}
In this paper we are study about wireless antenna, which are used for wireless communication, the wireless communication system are having important role in service requirement. We are design and analyzed the Dual Band type H Shaped Rectangular Microstrip Patch Antenna and Sparameters are finding out using of various Substrate height $(\mathrm{H})$.
\end{abstract}

Keywords: Simulation; Rectangular Microstrip Patch Antenna; S- Parameter.

Cite This Article: Saima Tabassum Mansoori, and Prof. Rahul Koshta. (2017). "DESIGN AND ANALYSIS OF DUAL BAND H SHAPED RECTANGULAR MICROSTRIP PATCH ANTENNA." International Journal of Research - Granthaalayah, 5(10), 369-374. https://doi.org/10.29121/granthaalayah.v5.i10.2017.2315.

\section{Introduction}

The most common type of microstrip antenna is the patch antenna. Antennas using patches as constitutive elements in an array are also possible.

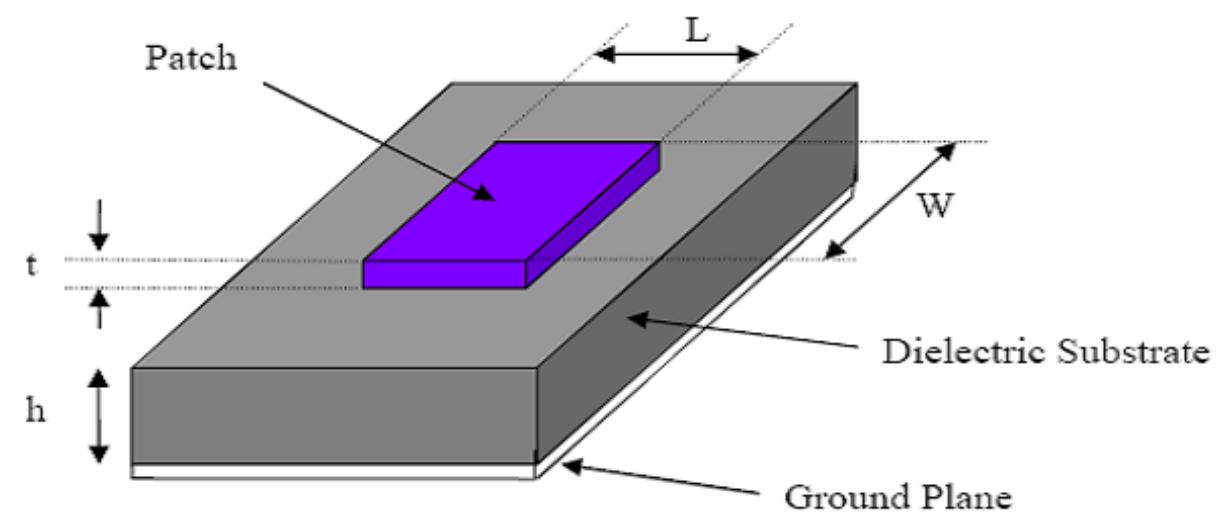

Figure 1: Microstrip antenna 


\section{Rectangular, Single Polarization Microstrip Antennas}

The figure below shows the geometry of the rectangular microstrip antenna, not including the ground plane and dielectric which would be underneath.

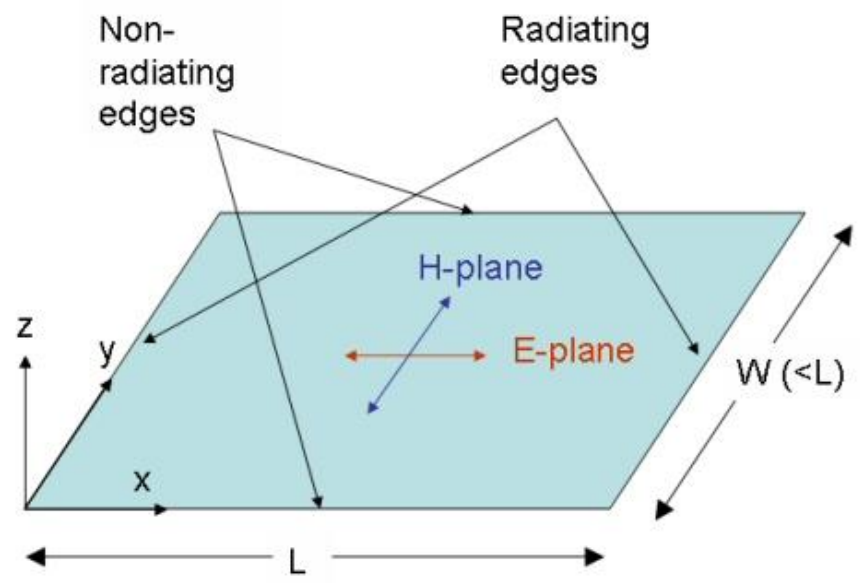

Figure 2: single polarization microstrip antenna

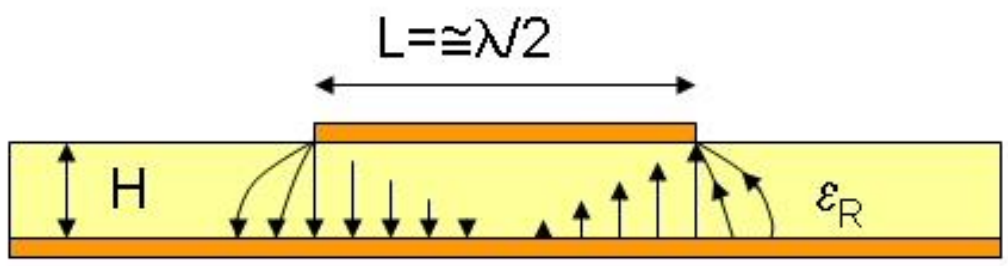

Figure 3: side view of single polarization microstrip antenna

\section{Results and Discussion}

\subsection{Substrate height $(\mathrm{H})$ are $3.2 \mathrm{~mm}$}

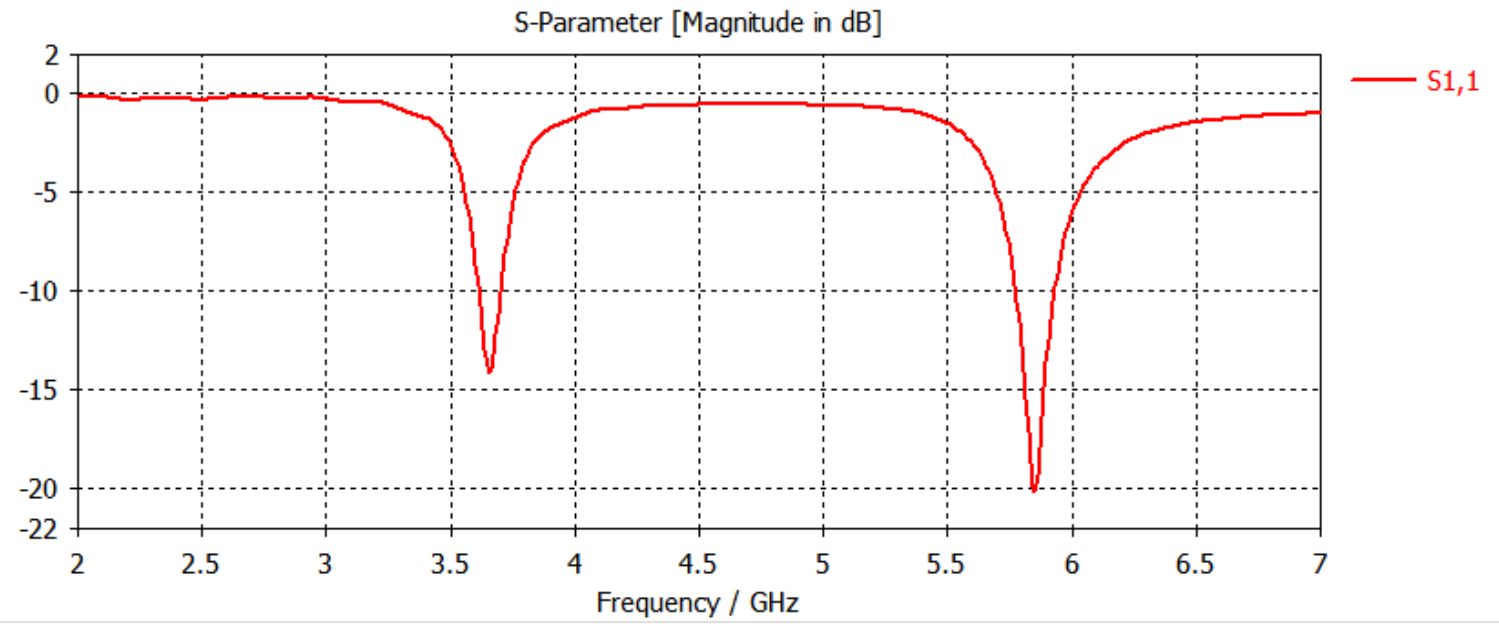

Figure 4: S-Parameter, Substrate height $(\mathrm{H})$ are $3.2 \mathrm{~mm}$ 
The antenna has the return loss of $-14 \mathrm{~dB}$ at the $3.655 \mathrm{GHz}$ and $-20 \mathrm{~dB}$ at $5.851 \mathrm{GHz}$. By using of Substrate height $(\mathrm{H})=3.2 \mathrm{~mm}$.

\subsection{Substrate height $(\mathrm{H})$ are $3.25 \mathrm{~mm}$}

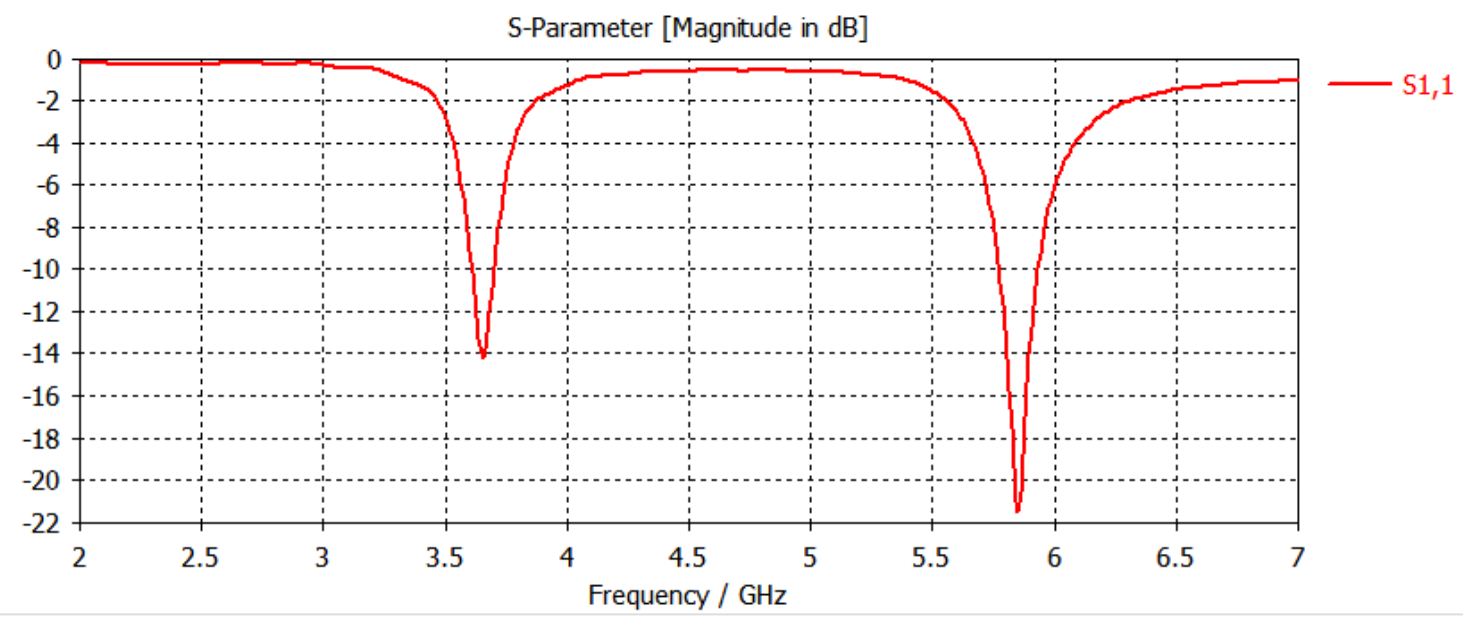

Figure 5: S-Parameter, Substrate height $(\mathrm{H})$ are $3.25 \mathrm{~mm}$

The antenna has the return loss of $-14 \mathrm{~dB}$ at the $3.655 \mathrm{GHz}$ and $-21.5 \mathrm{~dB}$ at $5.851 \mathrm{GHz}$. By using of Substrate height $(\mathrm{H})=3.25 \mathrm{~mm}$.

\subsection{Substrate height $(\mathrm{H})$ are $3.3 \mathrm{~mm}$}

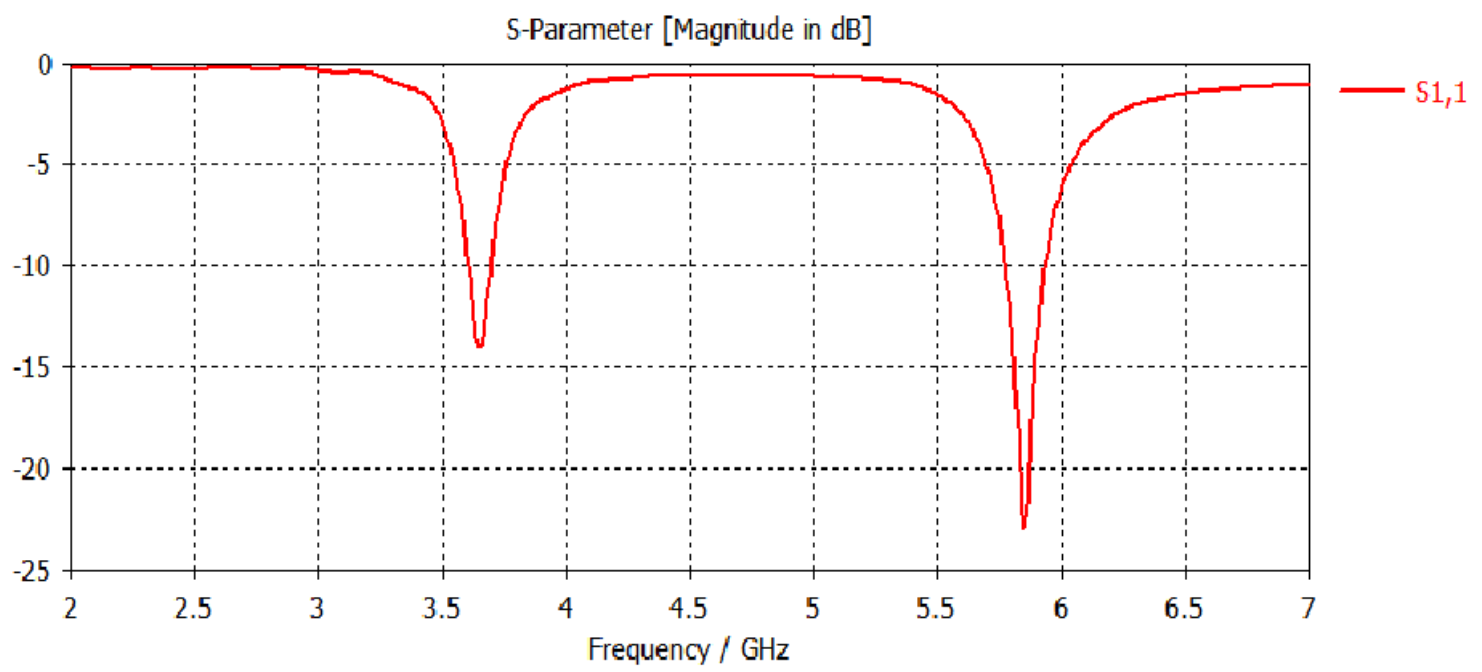

Figure 6: S-Parameter, Substrate height $(\mathrm{H})$ are $3.3 \mathrm{~mm}$

The antenna has the return loss of $-14 \mathrm{~dB}$ at the $3.655 \mathrm{GHz}$ and $-23 \mathrm{~dB}$ at $5.851 \mathrm{GHz}$. By using of Substrate height $(\mathrm{H})=3.3 \mathrm{~mm}$. 


\subsection{Substrate height $(\mathrm{H})$ are $3.35 \mathrm{~mm}$}

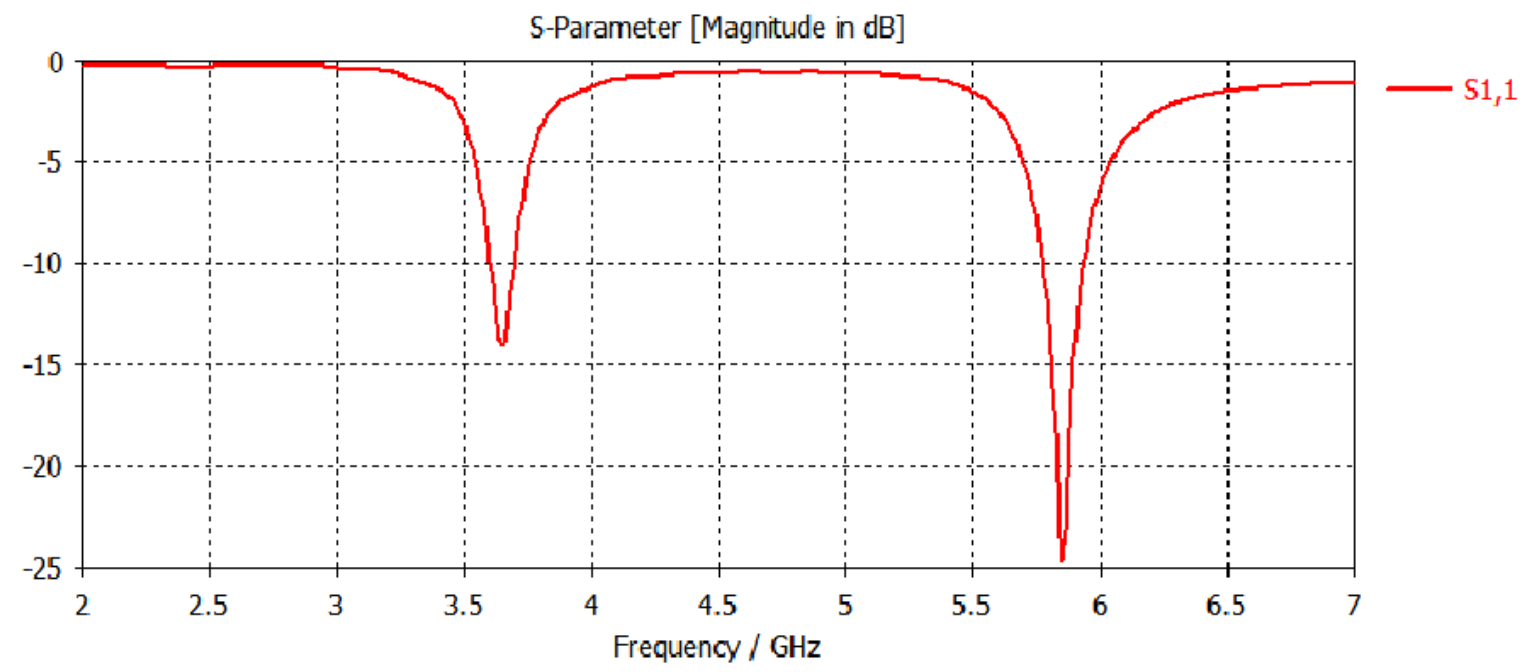

Figure 7: S-Parameter, Substrate height $(\mathrm{H})$ are $3.35 \mathrm{~mm}$

The antenna has the return loss of $-14 \mathrm{~dB}$ at the $3.655 \mathrm{GHz}$ and $-24 \mathrm{~dB}$ at $5.851 \mathrm{GHz}$. By using of Substrate height $(\mathrm{H})=3.35 \mathrm{~mm}$.

\subsection{Substrate height $(\mathrm{H})$ are $3.4 \mathrm{~mm}$}

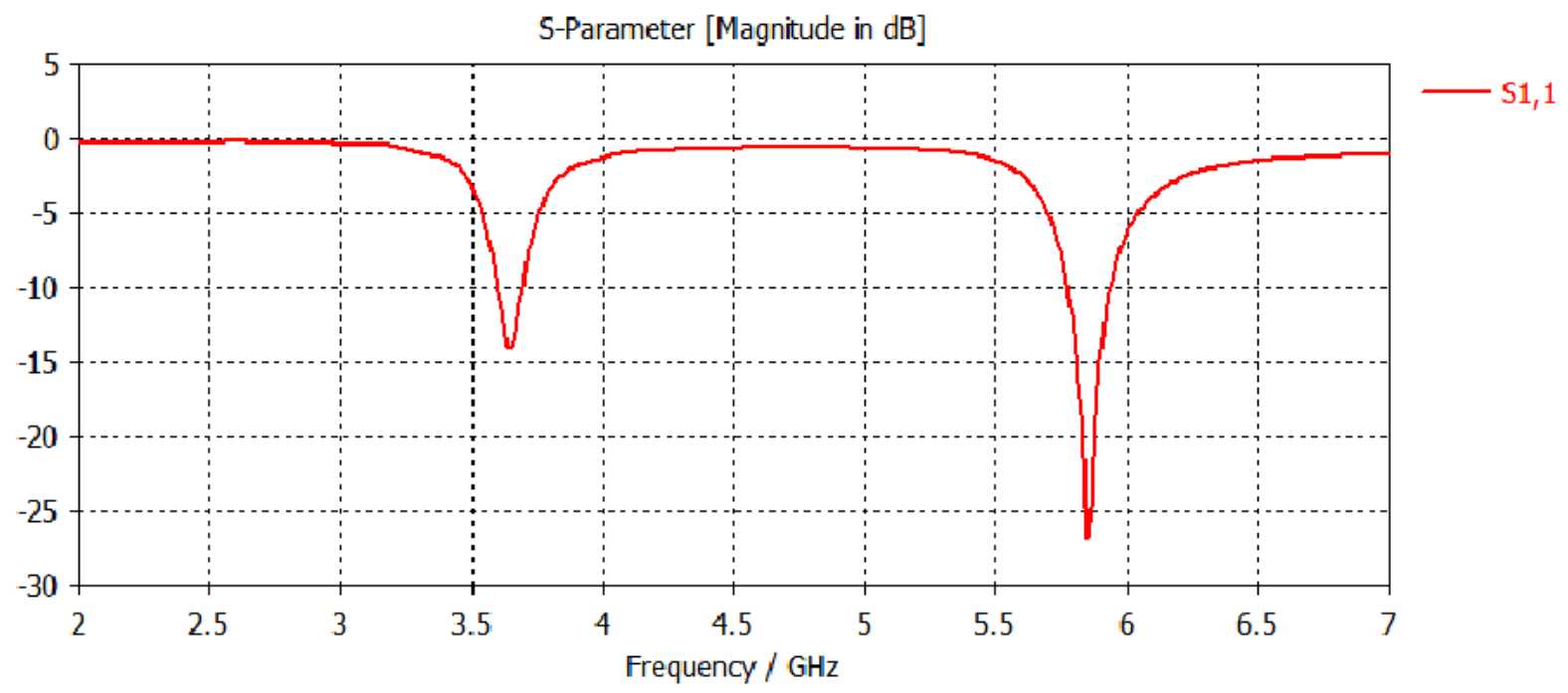

Figure 8: S-Parameter, Substrate height $(\mathrm{H})$ are $3.4 \mathrm{~mm}$

The antenna has the return loss of $-14 \mathrm{~dB}$ at the $3.655 \mathrm{GHz}$ and $-27 \mathrm{~dB}$ at $5.851 \mathrm{GHz}$. By using of Substrate height $(\mathrm{H})=3.4 \mathrm{~mm}$. 


\subsection{Substrate height $(\mathrm{H})$ are $3.45 \mathrm{~mm}$}

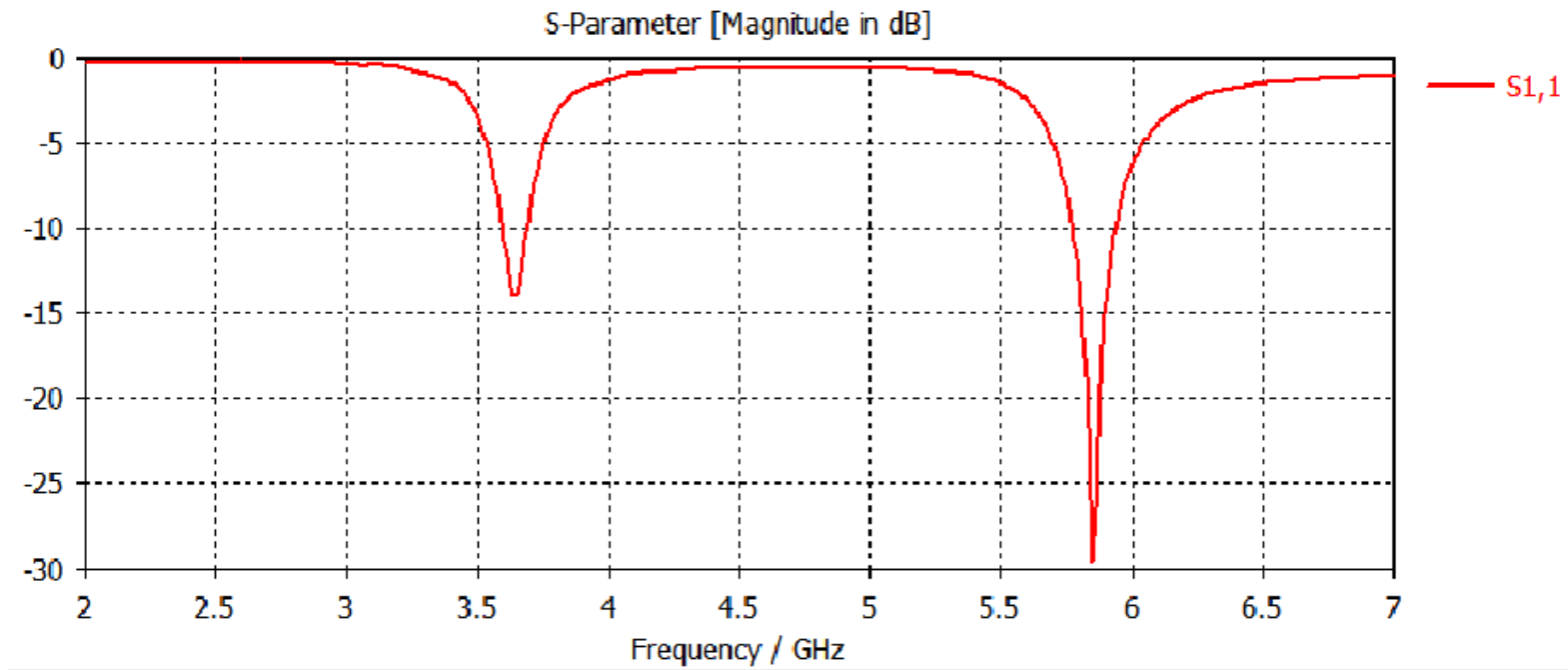

Figure 9: S-Parameter, Substrate height $(\mathrm{H})$ are $3.45 \mathrm{~mm}$

The antenna has the return loss of $-14 \mathrm{~dB}$ at the $3.655 \mathrm{GHz}$ and $-29 \mathrm{~dB}$ at $5.851 \mathrm{GHz}$. By using of Substrate height $(\mathrm{H})=3.45 \mathrm{~mm}$.

\subsection{Substrate height $(\mathrm{H})$ are $3.5 \mathrm{~mm}$}

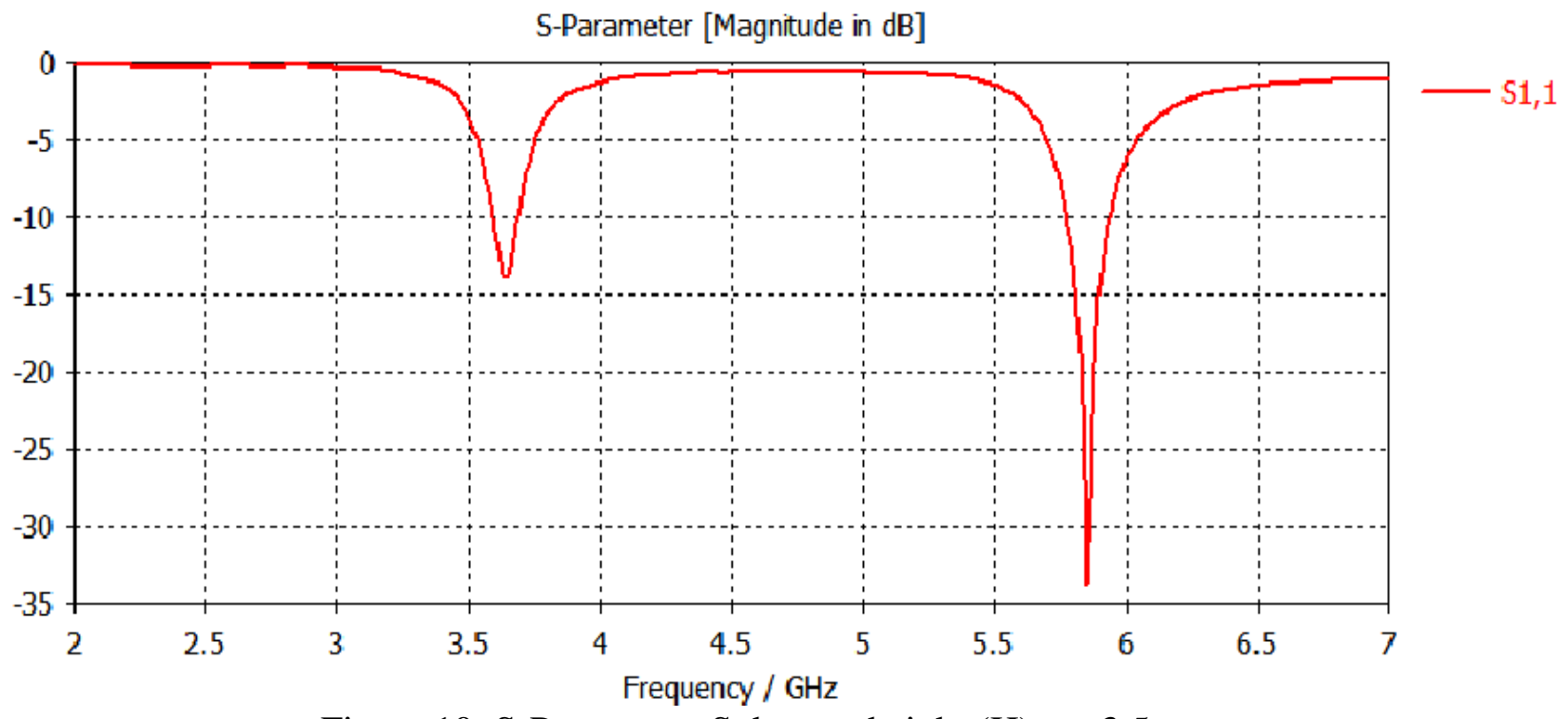

Figure 10: S-Parameter, Substrate height $(\mathrm{H})$ are $3.5 \mathrm{~mm}$

The antenna has the return loss of $-14 \mathrm{~dB}$ at the $3.655 \mathrm{GHz}$ and $-34 \mathrm{~dB}$ at $5.851 \mathrm{GHz}$. By using of Substrate height $(\mathrm{H})=3.5 \mathrm{~mm}$. 


\subsection{Substrate height $(\mathbf{H})$ are $3.55 \mathrm{~mm}$}

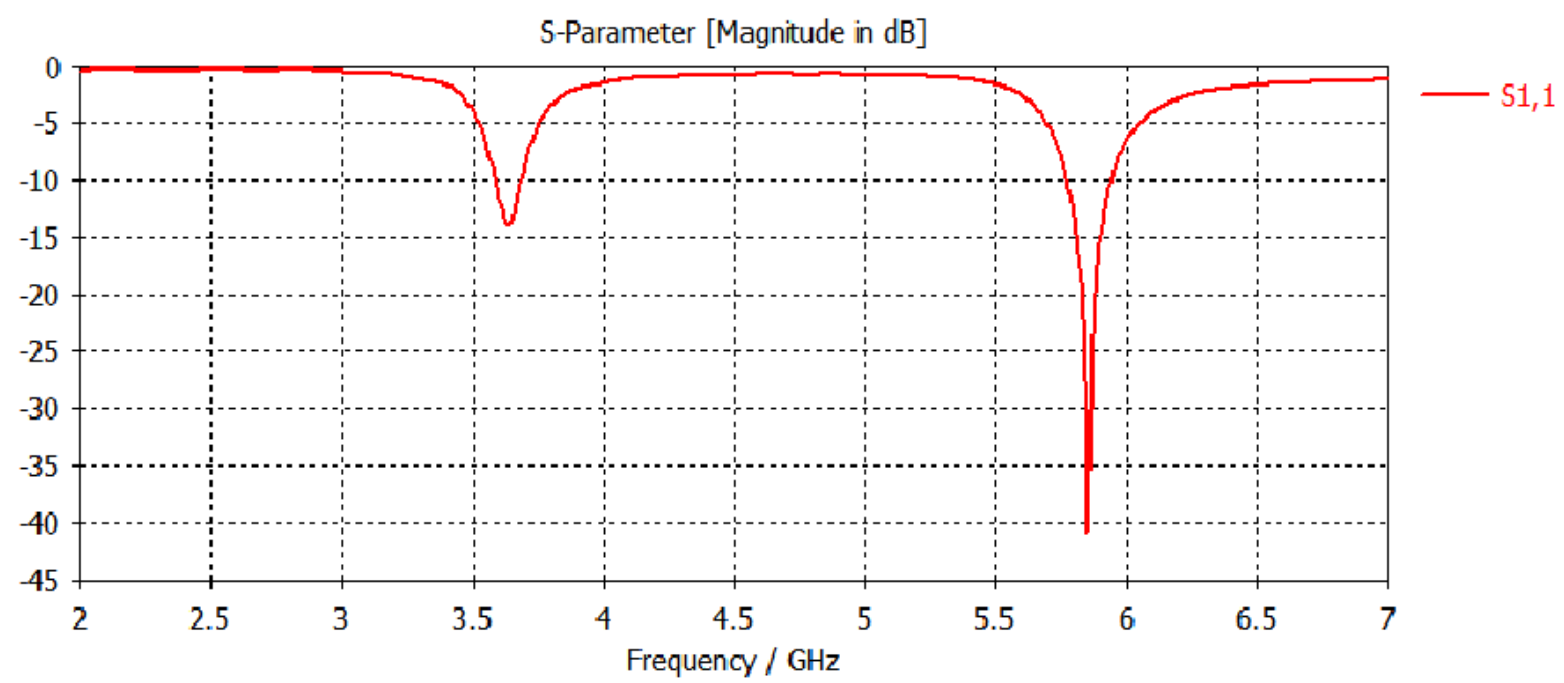

Figure 11: S-Parameter, Substrate height $(\mathrm{H})$ are $3.55 \mathrm{~mm}$

The antenna has the return loss of $-14 \mathrm{~dB}$ at the $3.655 \mathrm{GHz}$ and $-40.5 \mathrm{~dB}$ at $5.851 \mathrm{GHz}$. By using of Substrate height $(\mathrm{H})=3.55 \mathrm{~mm}$.

\section{Conclusion}

The antenna has the return loss of $-14 \mathrm{~dB}$ at the $3.655 \mathrm{GHz}$ and $-40.5 \mathrm{~dB}$ at $5.851 \mathrm{GHz}$. By using of Substrate height $(\mathrm{H})=3.55 \mathrm{~mm}$. Antenna design has turned to focus on wide multiband Some easy tuning steps to achieve dual-band operation. These type antennas are widely used in communication system.

\section{References}

[1] A.Kasinathan, "E-Shape Microstrip Patch Antenna Design for Wireless Applications" Vol. 1 Issue 3, May 2014.

[2] Darshana R. Suryawanshi, "A Compact Rectangular Monopole Antenna with Enhanced Bandwidth", Volume 9, Issue 2, PP 54-57.

[3] Nasser Ojaroudi "UWB/Omni-Directional Microstrip Monopole Antenna for Microwave Imaging Applications".Vol. 47, 139- 146, 2014.

[4] T.Suganthi, "Design and Analysis of Rectangular Microstrip Patch Antenna for GSM Application", Vol. 1 Issue 2, April 2014.

[5] Q. Zhao, "Compact wideslot tri band antenna for WLAN/WIMAX applications", Vol. 18, 9-18, 2010 . 